\title{
К ВОПРОСУ О РОЛИ МАЛОГО ПРЕДПРИНИМАТЕЛЬСТВА В УСЛОВИЯХ ЦИФРОВИЗАЦИИ ЭКОНОМИКИ
}

\author{
(C) 2018 Коновалова Мария Евгеньевна \\ доктор экономических наук, зав. кафедрой экономической теории \\ Самарский государственный экономический университет \\ 443090, г. Самара, ул. Советской Армии, д. 141 \\ E-mail: mkonoval@mail.ru \\ (c) 2018 Фомин Евгений Пименович \\ доктор экономических наук, профессор \\ зав. кафедрой налогов и налогообложения, проректор по экономическому развитию \\ Самарский государственный экономический университет \\ 443090, г. Самара, ул. Советской Армии, д. 141 \\ E-mail: fomin@sseu.ru
}

В представленной статье исследуются вопросы развития малого предпринимательства в условиях цифровизации социально-экономической системы. Рассматриваются основные характеристики цифровой экономики, раскрываются закономерности ее становления в различных секторах экономики России. Обосновывается необходимость институционального регулирования малого предпринимательства в процессе формирования цифровой модели экономики.

Ключевые слова: малое предпринимательство, цифровая экономика, цифровизация, краудфайндинг, IT-сектор, финансовые технологии

Трансформация социально-экономической системы наблюдаемая в последние годы обусловлена бурным развитием и внедрением информационных, в том числе цифровых технологий. Именно прогресс в IT-секторе создал предпосылки для расширения традиционных сегментов экономики и перевода их на принципиально новую модель развития. Особенностью происходящих процессов является проникновение цифровых технологий практически во все сферы жизнедеятельности человека, что в конечном итоге создает условия для повышения уровня благосостояния общества. Информационные технологии оказывают влияние на механизмы инвестирования, взаимодействия между экономическими акторами, обусловливая формирование горизонтального типа их координации. Особенно заметно влияние информационных технологий в финансовой сфере, так как именно в ней появилось значительное количество новых инструментов, которые расширяют инвестиционные возможности макроэкономических субъектов и создают предпосылки для развития малого бизнеса.

За последние пять-десять лет Россия переживает настоящую технологическую, телекоммуникационную революцию. Десятки миллио- нов россиян быстро привыкают к ежедневному использованию мобильного интернета, мобильных устройств, онлайн-платежей. Для того, чтобы Россия могла успешно и в будущем поддерживать темпы цифровизации необходимы современные технологии, такие как Биг Дата, технологии распределенных реестров, виртуальная и дополненная реальность искусственный интеллект, квантовые технологии и т.п. Цифровая экономика - это не просто количество граждан, имеющих доступ в интернет, это изменение традиционных отраслей народного хозяйства под влиянием цифровой трансформации. Развитие новой экосистемы требует развития как крупного бизнеса, то есть операторов цифровых платформ, так и малых фирм и организаций, которые смогут реализовать стартапы, искать новые идеи, апробировать их, развивая при этом различные отрасли экономики. В течение последующих пяти дет панируется масштабное увеличение инвестирования в объеме до 130 миллиардов рублей в развитие передачи информации, центров обработки и хранения данных. Объем цифровой экономики необходимо утроить и приблизить к уровню ведущих стран мира до 2025 года. В настоящий период времени цифровая экономика составляет примерно 4\% ВВП, 
и это в 2-3 раза меньше, чем в странах-лидерах. Тем не менее в российской экономике есть все необходимые предпосылки роста скорости внедрения цифровых технологий. Так, например, Россия является бесспорным лидером в возможностях предоставления широкополосного интернета, развития поисковых систем, таких, например, как «Яндекс», скорости внедрения интернет-платформ, реализующих новые инвестиционные механизмы.

Малый бизнес, как известно, обладает определенными преимуществами, среди которых мобильность, приспособляемость к изменению рыночной конъюнктуры, конкурентоспособность и т.д., что позволяет именно ему занять необходимые ниши в процессе формирования цифровой модели экономики. В принятой программе «Цифровая экономика Российской Федерации» от 28 июля 2017 года поставлена цель. Создать необходимые условия для стимулирования использования цифровых инноваций всеми хозяйствующими субъектами. Как нам видится, реализация предложенных мероприятий будет способствовать роту конкурентоспособности малого бизнеса, в основе которого лежит использование инструментов цифровизации. Вопросы взаимодействия предприятий малого бизнеса и цифровой экономики являются как никогда актуальными в настоящее время, так как именно данная новая сфера позволяет развиваться малым инновационным предприятиям, использующим новейшие IT -технологии. Проблемы стимулирования развития предприятий малой формы бизнеса требуют скорейшего решения, поскольку именно малый бизнес выполняет социально-значимые функции, реализация которых позволяет повысить занятость населения, а значит и уровень благосостояния общества.

Говоря о сущности предпринимательской деятельности, следует заметить, что в научной литературе существуют достаточно обширный перечень определений данной дефиниции. Различные авторы акцентируют внимание на разнообразных характеристиках предпринимательства, тем не менее можно выделить ряд общих черт, присущих ему. Во-первых, это извлечение прибыли, как основной цели функционирования малых предприятий; во-вторых, это осуществление предпринимательской деятельности в условиях риска и неопределенности; в-третьих, это создание необходимых обществу благ, обеспечивающих платежеспособный спрос населения; в-четвертых, сама предпринимательская деятельность является творческой, инновационной, самостоятельной, предполагающей применение нетрадиционных способов к решению различных ситуаций.

В процессе становления цифровой экономики предпринимательская деятельность связана непосредственно с компетенциями самого предпринимателя, его способностями к обработке информации, ее пониманию и возможности извлечения максимальной прибыли. Несомненно, успешность малого бизнеса будет во многом определяться качеством высокотехнологичной продукции, произведенной с помощью цифровых технологий. Не стоит, однако, забыть, что развитие цифровизации порождает определенные риски, связанные с реализацией новых инвестиционных инструментов, таких как народное кредитование (краудфайдинг), коллективное инвестирование (краудлейдинг) и др. В этой ситуации существенно возрастают системные предпринимательские риски, которые необходимо будет нивелировать с целью сохранения стабильности сегмента малого бизнеса. На успешное развитие малых предприятий в условиях становления цифровой модели экономики влияют множество факторов. Основными негативными ограничениями, препятствующими динамичному росту малого бизнеса в настоящий период времени являются, прежде всего, недостаточная компетентность руководителя организации, недостаточный опыт в управлении производством, поставками продукции, логистическими схемами и т.д.

Развитие цифровизации предполагает наличие и эффективное функционирование институтов, создающих условия и стимулирующих внедрение информационных технологий в различные сегменты экономики. Не секрет, что эффективно действующие институты формируют условия для экономического роста, а качественная институциональна среда является, по сути, императивом социально-экономического развития в целом. В настоящее время наиболее злободневная проблема связана с правовых регулированием процессов цифровизации, с легимитизацией новых финансовых инструментов, применяемых при коллективным финансировании и инвестировании. Основные вопросы, требующие разрешения связаны с нормативно-правовым регулированием, особенно в области функционирования крипторынков, и 
цифровых платформ. В текущий момент очень быстрыми темпами создаются цифровые платформы, в частности, платформа индустриального интернета. Данные платформы найдут свое применение в нефтегазодобыче, энергетике, машиностроении и сельском хозяйстве.

Отдельными вопросами, требующими определенной проработки является взаимодействие с органами МВД, которые сталкиваются с мошенническими действиями интернет-продавцов и покупателей, разработкой поправок в Уголовный кодекс и Кодекс об административных правонарушениях. Например, необходимо четко узаконить интернет-торговлю на законодательном уровне и защитить российского потребителя, приобретающего товары и услуги через онлайн - агрегаторов. В настоящее время разработано уже более 50 законопроектов, реализация которых, по сути, приведет к революции с точки зрения понимания и использования государством технологий в интересах граждан.

Развитие цифровизации сопровождается трансформацией практически всех сфер жизнедеятельности общества, что говорит о формировании новой парадигмы социально-экономического развития.

Внедрение новых инструментов инвестирования, а также способов координации хозяйствующих субъектов способствуют росту количества малых инновационных предприятий.

Наиболее привлекательными сферами для предприятий малой формы бизнеса являются инвестиционные платформы, реализующие модели краудфайдинга и краудлендинга.

Основной задачей становления и развития цифровой экономики является создание эффективно работающей институциональной среды, обеспечивающей нормативно-правовое регулирование цифровизации.

\section{Библиографический список}

1. Буров В.Ю., Капитонова Н.В., Кайбалина Н.Б. О роли малого предпринимательства и образования в развитии цифровой экономики // Фундаментальные исследования. 2018. № 4. С. 44-49

2. Белинская Д.Б. Развитие цифровой экономики в Российской Федерации // Экономика и предпринимательство. 2017. № 12. С.30-33.

3. Стратегия развития Сбербанка до 2010 года [электронный ресурс] режим доступа: http://www.sberbank.ru/ common/img/uploaded/files/sberbankdevelopmentstrategyfor2018

4. Стратегия развития информационного общества в Российской Федерации (Утверждена Президентом Российской Федерации В.В. Путиным 7 февраля 2008 г. № Пр-212) Режим доступа: http://economy.gov.ru/ minec/activity/sections/infOrientedSoc/doc20080207_01

5. Бакиева М.Ю. Финансовые инновации в Российской экономике// Вестник СГСЭУ. 2018. № 3 (72). С. 16-19. 